\title{
Emergence of West Nile virus infections in humans in Turkey, 2010 to 2011
}

H Kalaycioglu (h.kalaycioglu@hotmail.com) ${ }^{1}$, G Korukluoglu¹, A Ozkul ${ }^{2}, 0$ Oncul ${ }^{1}$, S Tosun 3 , 0 Karabay ${ }^{4}$, A Gozalan ${ }^{1}$, Y Uyar ${ }^{1}$,

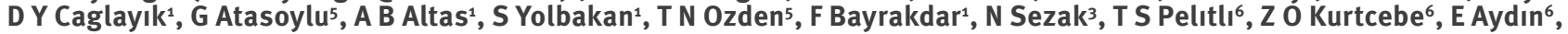
M Ertek ${ }^{1}$

1. Refik Saydam National Public Health Agency, Ankara, Turkey

2. Ankara University, Faculty of Veterinary Medicine, Department of Virology, Ankara, Turkey

3. State Hospital, Manisa, Turkey

4. Training and Research Hospital, Sakarya, Turkey

5. Provincial Health Directorate, Manisa, Turkey

6. Ministry of Health, General Directorate of Primary Health Care, Ankara, Turkey

Citation style for this article:

Kalaycioglu H, Korukluoglu G, Ozkul A, Oncul O, Tosun S, Karabay O, Gozalan A, Uyar Y, Caglayık DY, Atasoylu G, Altas AB, Yolbakan S, Ozden TN, Bayrakdar F,

Sezak N, Pelıtlı TS, Kurtcebe ZO, Aydın E, Ertek M. Emergence of West Nile virus infections in humans in Turkey, 2010 to 2011. Euro Surveill. 2012;17(21):pii=20182. Available online: http://www.eurosurveillance.org/ViewArticle. aspx?Articleld=20182

Article submitted on 11 November 2011 / published on 24 May 2012

In 2010, 47 human cases of West Nile virus (WNV) infection, including 12 laboratory-confirmed and 35 probable cases, were identified in Turkey. These were the first cases detected during routine surveillance. The patients were from 15 provinces, mainly located in the western part of the country. Incidence was $0.19 / 100,000$ with a maximum of 1.39 in Sakarya province. Forty of the total 47 cases showed neuroinvasive manifestation. Median age was 58 years with a range of four to 86. Ten of the patients died. Enhanced surveillance in humans and animals and mosquito control measures were implemented. The WNV infections were included in the national notifiable diseases list as of April 2011. In 2011, three probable and two confirmed cases of WNV infection were diagnosed in provinces where infections had been detected in the previous year, supporting a lower activity than 2010. However, detection of WNV infections in humans in 2010 and 2011 consecutively, may indicate that WNV has become endemic in the western part of Turkey. Field epidemiological studies were undertaken to understand more about the nature of infection in Turkey.

\section{Introduction}

On 12 August 2010, the Manisa Provincial Health Directorate and the Ministry of Health in Turkey were informed about an increase in the number of hospitalised patients with encephalitis-like symptoms of unknown etiology. A preliminary case definition based on the clinical picture, and a case management algorithm were immediately set up by a Scientific Commission at national level, consisting of experts from universities and from the Ministry of Health $(\mathrm{MOH})$, and sent to provincial health facilities. A viral infection including possibly West Nile virus (WNV) was suspected. According to the case management algorithm, the blood and cerebrospinal fluid (CSF) samples of suspected cases were sent to national reference laboratories, Refik Saydam
National Public Health Agency (RSNPHA) and Ankara University Faculty of Veterinary Medicine, for further analysis. Of 12 suspected cases from Manisa province, three tested positive for WNV infection by serology and neutralisation, while another showed a WNV-specific antibody response in a serum sample. These were the first acute human WNV infection cases documented in Turkey. Prior to this first cluster of WNV cases, WNV infections were not notifiable in Turkey. Neuroinvasive cases were probably diagnosed as 'viral meningitis' and not investigated further.

At the time when the first cluster of human WNV cases was determined in Turkey, human cases were also reported from Greece, Russia and Israel as well as equine cases from Morocco [1,2]. In 2010, human WNV infection epidemics in Europe occurred in Greece, Italy and Romania. In Greece, 262 probable and confirmed cases were reported, including 197 neuroinvasive cases and 33 deaths [2]. In Romania, a total of 57 cases of WNV infection (54 with neuroinvasive infection and three febrile cases) were identified between July and October 2010 [3]. In Italy, human cases of WNV infection, including three confirmed cases of neuroinvasive disease and three confirmed cases of West Nile fever were identified in the north-eastern part of country and they were detected through the enhanced regional surveillance plan for West Nile fever [4]. In 2010, WNV infections in humans were also reported from other European countries, such as Hungary (15 cases), Portugal (1 suspected case) and Spain (1 confirmed case) [5].

The 2011 West Nile virus season started in July in Europe, with 96 confirmed human cases reported by the end of the season (November). As of 24 November 2011, 93 confirmed human cases of West Nile fever had been reported in the European Union: 69 cases 
in Greece, 14 in Italy and 10 in Romania. In the neighbouring countries, 189 cases had been declared: two in Albania, four in the Former Yugoslav Republic of Macedonia, 33 in Israel, 136 in the Russian Federation, three in Tunisia, three in Turkey and eight cases in Ukraine $[6,7]$.

This study describes the human WNV infection cases identified in Turkey between July 2010 and December 2011.

\section{Methods}

\section{Surveillance}

In August 2010, following the detection of seven cases with encephalitis-like symptoms including one fatal case, the Ministry of Health issued an alert and strengthened the surveillance by formulating a case definition, and case and laboratory management algorithms. The initial case definition set up by the Scientific Commission was highly sensitive including non-neuroinvasive features such as skin rash. Once WNV infection had been established as cause, the case definition was revised and structured on identifying neuroinvasive disease. A standardised reporting form was developed including information on basic demographic characteristics, clinical manifestations and findings, main risk factors and underlying conditions.

In April 2011, WNV infections were included in the national notifiable diseases list with a case definition adapted from the European Union case definition for reporting communicable diseases to the Community network [8].

In addition to the national routine surveillance in the 2011 season, starting in July, the Health Directorates of Edirne, Manisa, Sakarya and Mugla provinces implemented active surveillance with an enlarged case definition including influenza-like illness to detect asymptomatic or subclinical cases of WNV infection.
Seropositivity study

Following the peak of WNV season, in October 2010, a seropositivity study was conducted on people living in close proximity to cases, in three provinces which showed high incidence. The aim of the study was to collect serum samples from persons who shared similar ecological conditions with WNV infection cases.

\section{Case definition}

People presenting fever with unknown etiology and at least one of the clinical signs or findings of meningitis or encephalitis or meningoencephalitis or myelitis, such as sudden alteration of mental status, acute signs of central or peripherial neurological dysfunction, stiffness of neck, acute flaccid paralysis or cranial and peripheral neuritis, other neuropathies including Guillain-Barré syndrome were considered 'suspected' and tested for WNV-specific IgM and IgG antibodies with enzyme-linked immunosorbent assay (ELISA) or immunofluorescence test (IFA). The first 12 positive cases by IFA were analysed with plaque-reduction neutralisation test (PRNT) which was used for confirmation.

A case was considered as 'probable' if WNV-specific antibody response was demonstrated in their serum sample by ELISA and IFA, and 'confirmed' if PRNT was positive or specific IgM antibodies were detected in the CSF or an increasing titre of WNV-specific IgM was demonstrated in their serum sample. The cases presenting clinically with meningitis/encephalitis or meningoencephalitis were considered as having neuroinvasive disease.

An exception in diagnosis was made for a deceased patient where the sample was negative in ELISA and IFA. It was further analysed with PRNT as there was no chance of assessing seroconversion. The patient was accepted as a confirmed case, as PRNT was found positive.

\section{FIGURE 1}

Reported cases of West Nile virus infections by onset of illness, Turkey, 28 June-31 December 2010 ( $\mathrm{n}=47)$

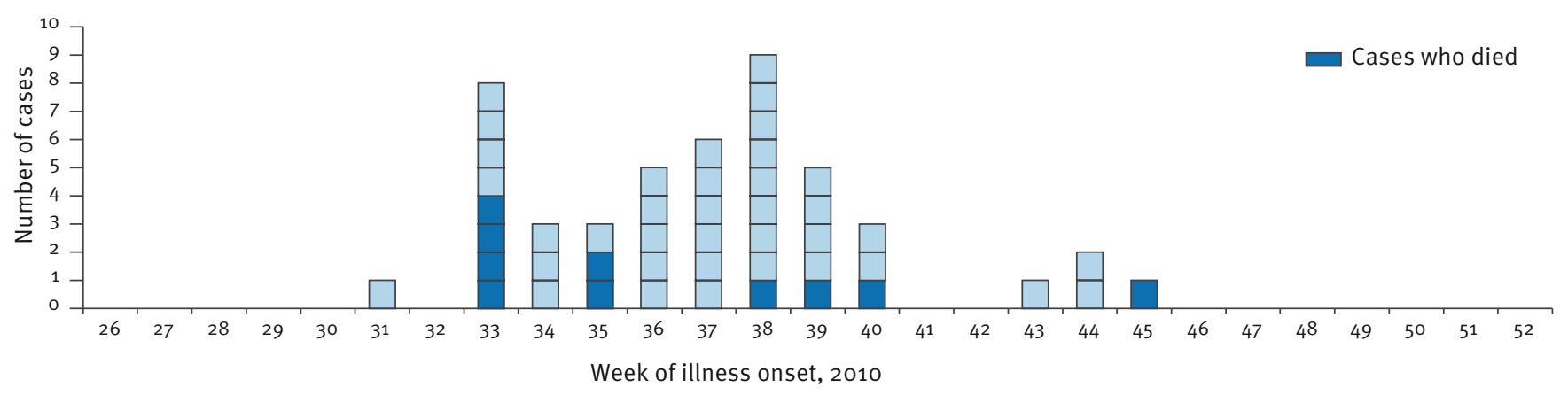


Number and incidence of reported cases of West Nile virus infections by age group and province of residence, Turkey, July-November $2010(\mathrm{n}=47)$

\begin{tabular}{|c|c|c|}
\hline Characteristic & $\begin{array}{l}\text { Number of } \\
\text { cases }\end{array}$ & $\begin{array}{c}\text { Incidence } \\
\text { (per 100,000 population) }\end{array}$ \\
\hline \multicolumn{3}{|c|}{ Age group (years) } \\
\hline$<20$ & 8 & 0.10 \\
\hline $20-29$ & 3 & 0.07 \\
\hline $30-39$ & 1 & 0.03 \\
\hline $40-49$ & 6 & 0.19 \\
\hline $50-59$ & 8 & 0.33 \\
\hline $60-69$ & 4 & 0.28 \\
\hline $70-79$ & 12 & 1.29 \\
\hline$\geq 80$ & 5 & 1.63 \\
\hline \multicolumn{3}{|c|}{ Province of residence } \\
\hline Ankara & 1 & 0.02 \\
\hline Adana & 1 & 0.05 \\
\hline Antalya & 1 & 0.05 \\
\hline Kocaeli & 1 & 0.06 \\
\hline Afyon & 1 & 0.14 \\
\hline Konya & 3 & 0.15 \\
\hline Manisa & 2 & 0.15 \\
\hline Izmir & 8 & 0.21 \\
\hline Isparta & 1 & 0.24 \\
\hline Balikesir & 3 & 0.26 \\
\hline Diyarbakir & 4 & 0.26 \\
\hline Aydin & 4 & 0.41 \\
\hline Karaman & 1 & 0.43 \\
\hline Mugla & 4 & 0.50 \\
\hline Sakarya & 12 & 1.39 \\
\hline Total & 47 & 0.19 \\
\hline
\end{tabular}

\section{Laboratory methods}

Acute and convalescence period serum samples were collected from all suspected cases upon the first day of hospitalisation, within 8 to 14 days and at 21 days after the onset of illness to be tested by ELISA and IFA to find IgG and IgM antibodies against WNV, and by PRNT to detect specific neutralising antibodies. The samples were transported at $+4^{\circ} \mathrm{C}$ and stored at $-25^{\circ} \mathrm{C}$ until testing. Serological tests were performed by the national reference laboratory (RSNPHA), Virology Reference Laboratory, Novel and Dangerous Pathogens Unit in Ankara. Samples were analysed by using West Nile virus ELISA and IFA tests (anti-West Nile virus ELISA IgG and IgM Euroimmun, Lübeck Germany; IIFT Flavivirus Mosaic 1 IgG ve IgM Euroimmun, Lübeck Germany). Tests were performed according to the protocol of the manufacturer.

IFA test contained antigens to Flavivirus Mosaic 1 (Euroimmun, Lübeck Germany), tick- borne encephalitis virus (TBEV), yellow fever virus (YFV), West Nile virus (WNV) and Japanese encephalitis virus (JEV).
In order to detect and/or discriminate WNV specific neutralising antibodies, PRNT was performed as a confirmation test by the Virology Department in the Faculty of Veterinary Medicine, Ankara University. The test was carried out as previously described by Ozkul et al, 2006 [9], using WNV/NY99 strain (200 plaque forming units (PFU) per reaction). Serum samples that neutralised the challenge virus $>70 \%$ were regarded as seropositive.

\section{Data analysis}

Data were analysed using SPSS 15.0 software package, CHICAGO, IL, RSHMB 9887381. Incidence was calculated using 2009 Address Based Population Registration System from the Turkish Statistical Institute as denominator [10]. Towns with more than 20,000 inhabitants were considered as urban areas while others were considered as rural, according to the definitions of the Turkish Statistical Institute. Information on animal health was gathered from the surveillance data of the Ministry of Food, Agriculture and Husbandry.

\section{Results}

\section{Surveillance data 2010}

From July to November in 2010, 47 cases of WNV infection were detected, 40 with central nervous system manifestations, seven with non-neuroinvasive symptoms. Of these 47 cases, 35 were probable, 12 were confirmed. The overall incidence of WNV infections was 0.19 cases per 100,000 population, with the maximum of 1.39 in Sakarya province.

The first cases of WNV infection had onset of symptoms in late July and early August in 2010 (Figure 1). The cases cumulated between the second week of August and last week of September. The last case had onset of illness in the second week of November.

Some characteristics of reported WNV infection cases are shown in the Table. The median age of WNV infections cases was 58 years and the range four to 86 years, with most $(n=17)$ aged 70 years or older. The highest incidence was in the age group of 80 years or older and was 1.63 cases per 100,000 population. Of all WNV infection cases, 32 were males.

The place of residence of WNV infection cases is presented in the Table and in Figure 2. The WNV cases were from 15 provinces, mainly from the western part of the country. The highest incidence was in Sakarya province with 1.39 cases per 100,000 population, followed by Mugla, Karaman and Aydin provinces with incidences ranging from 0.4 to 0.5 cases per 100,000 population. The incidence was higher in the western part of the country except for Diyarbakir province which is located in the south-east of Turkey. The incidences of urban and rural areas were 0.22 and 0.27 (per 100,000) respectively. 


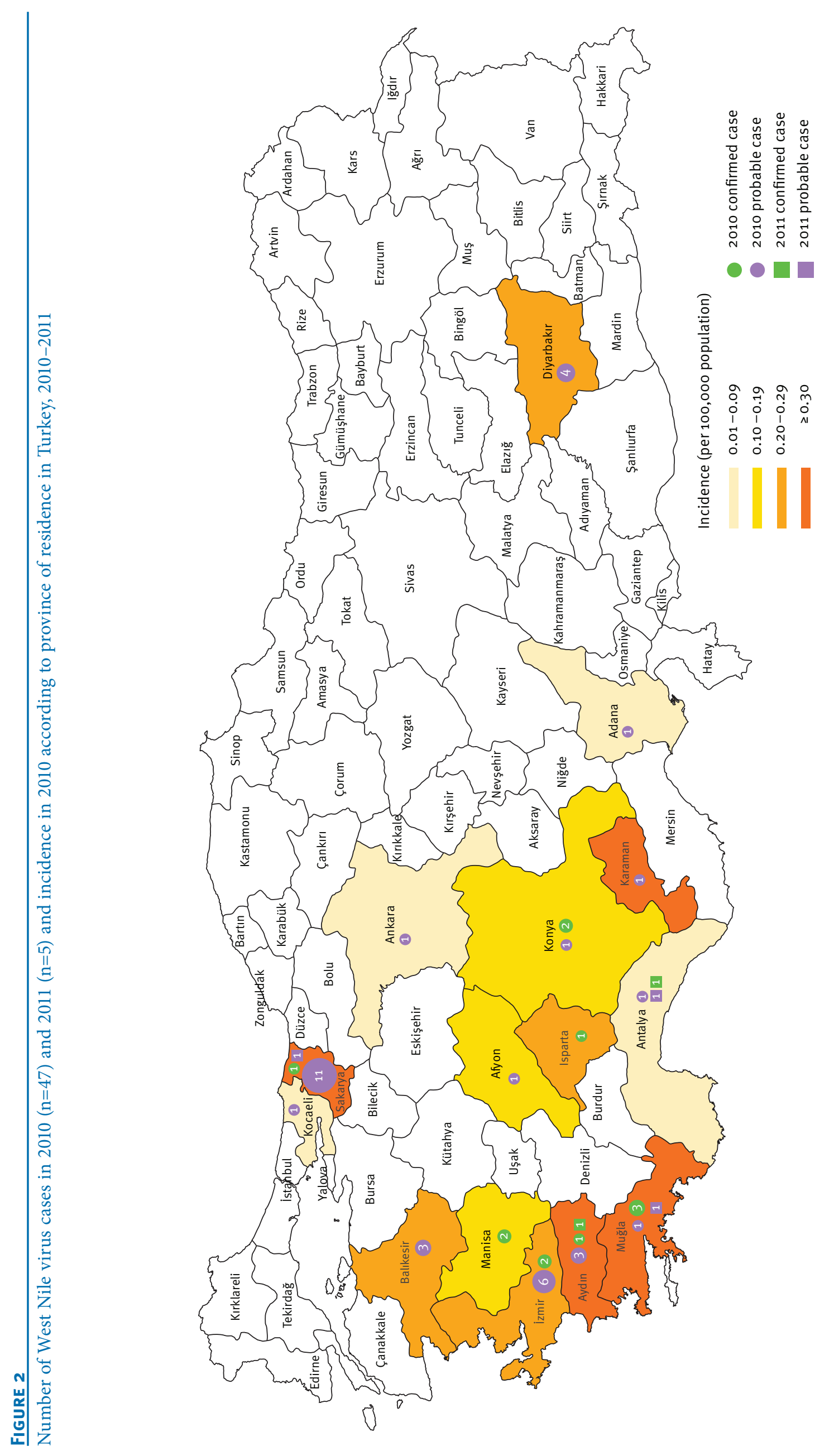


All WNV infection cases were hospitalised while four of them needed to be treated in intensive care units. The first attended service was mainly the emergency unit (58\%). The average length of stay in hospital was $19.6 \pm 21.5$ days (range: $2-120$ days).

The most common symptoms were fever $(n=40)$, headache $(n=34)$ and nausea/vomiting $(n=30)$. The alteration of consciousness $(n=23)$, convulsion $(n=6)$ and fainting $(n=5)$ were also observed.

Of the 47 cases, 10 died. Case fatality rate was $21 \%$. The median age was 76 in deceased patients with the range of 25 to 86 . Four of the fatal cases were residing in rural areas and six had underlying conditions such as diabetes mellitus, hypertension, chronicle obstructive pulmonary disease and psychiatric diseases.

WNV-specific IgM antibodies were detected in all 47 sera, while WNV-specific IgG antibodies were detected in 36 of 47 serum samples. The CSF samples could only be obtained from 10 of the patients whose serum samples were positive for IgM antibodies, but none of the CSF samples demonstrated positivity. The initial 12 serum samples that demonstrated WNV-specific antibody positivity with ELISA and IFA were tested with PRNT and all of them were found positive.

\section{Surveillance data 2011}

In 2011, three probable and two confirmed cases of WNV infections were identified in Turkey. The confirmed cases showed increasing titres of IgM WNVspecific antibodies. The probable cases were from Mugla, Sakarya and Antalya, the confirmed cases were from Aydin and Antalya Provinces, all of which had been affected in 2010. Two of the probable cases were identified through active surveillance that was conducted in Mugla and Sakarya in which influenzalike illness was included in the case definition. One of these two cases did not present any neurological manifestation. The WNV infection cases had an onset of illness between 5 and 25 August 2011. The places of residence of reported WNV infection cases are shown in Figure 2.

Seropositivity study in Mugla, Sakarya and Manisa provinces, October 2010

In addition to routine surveillance, a seropositivity study was conducted in three provinces (Mugla, Sakarya and Manisa) in October 2010, following the peak of epidemics. A total of 213 serum samples were collected, 40 from Mugla, 69 from Sakarya and 104 from Manisa provinces. The samples were analysed by ELISA and IFA in the national reference laboratory. Thirteen samples of 40 were seropositive in Mugla, 15 of 69 in Sakarya and four of 104 in Manisa (unpublished data from Refik Saydam National Public Health Agency).
Equine cases notified in 2010

Besides human cases, WNV infection was detected in two horses in Izmir province in September 2010. The equine cases were confirmed by neutralisation test performed by the Virology Department in the Faculty of Veterinary Medicine, Ankara University. These cases were notified by the Ministry of Food, Agriculture and Husbandry to the Ministry of Health. Both horses were from a private stud farm in Izmir Province, close to Manisa Province where the first cluster of human cases was determined. One of them died and the other one recovered without any complication. The Ministry of Food, Agriculture and Husbandry invited relevant sectors for an enhanced collaboration to reciprocally share information [11].

\section{Discussion and conclusions}

In Turkey, the first studies on the presence of arboviral infections in humans were carried out in the 1960 s. In 1980, a study was performed in the western part of Turkey (Aegean) which presented 29.1\% WNV seropositivity [12]. In recent studies from 2007 and 2010, WNV seropositivity was found to be $9.4 \%$ in the South-East and $0.56 \%$ in Central Anatolia for blood donors, while a $9.2 \% \lg M$ and $3.4 \% \lg G$ seropositivity were detected in patients with aseptic/viral meningitis/encephalitis [13-15].

Until 2010, WNV infections in humans had been subject to only field and clinical surveys in the country [12-15]. The infection had not been documented among routine health services until then. It was mainly because the infection was not a notifiable disease in Turkey. Other reasons are considered to be clinicians' lack of attention to most common forms of WNV infection which are asymptomatic or mild, and difficulties in laboratory diagnosis. As of April 2011, human WNV infections were included to the national notifiable diseases list.

The 2010 and 2011 cases of WNV infections in Turkey were observed in several provinces mostly in the western part. However, the previous studies had suggested that WNV infection was more widespread affecting other parts of the country such as Central Anatolia and the South-East [12-15]. Inclusion of WNV infections into national surveillance system covering the whole country and increasing awareness are expected to support the detection of cases in other regions of the country. On the other hand, detection of WNV infections in humans in 2010 and 2011 consecutively, may indicate that WNV has become endemic in the western part of Turkey.

The two cases of WNV infections in 2011 were identified through active surveillance conducted in four provinces. The case definition used in active surveillance included non-neuroinvasive symptoms in addition to neuroinvasive manifestations. As most human infections are asymptomatic and only $20 \%$ of infected WNV cases demonstrate clinical symptoms [16] it is 
estimated that the number of cases was higher than that reported.

The veterinarian surveillance of WNV is limited in Turkey. There are few studies indicating WNV activity in animals. The first seroepidemiological evidence for the presence of arbovirus infections in animals was demonstrated in the 1960s. In 2005, Ozkul et al found presence of neutralising antibodies to WNV in a variety of mammalian species [9]. The detection of two equine cases in Izmir province which was very close to first cluster of human cases in 2010 was supportive of virus circulation in this part of country.

This is the first time that acute WNV infections in humans have been documented in Turkey. Capacity building activities, including surveillance and intersectoral collaboration have been put into practice. Enhanced surveillance in humans and animals and mosquito control measures with the support of municipalities were implemented. The Ministry of Health will communicate the arrangements regarding blood safety procedures due to results of surveys. Field epidemiological surveys in vectors and blood donors are still underway covering four provinces (Manisa, Mugla, Sakarya and Edirne) and a seroprevalence study has started in March 2012. These investigations will help to understand more about the nature of WNV infections in Turkey and to provide evidence-based recommendations for blood safety procedures.

\section{Acknowledgements}

We thank to the staff of 15 Provincial Health Directorates and State and University Hospitals for their valuable field and clinical study, to Field Investigation Team (Galip Koroglu, Dilber Aktas, Mestan Emek and Esra Gul Akinci), to Scientific Commission Members (Hurrem Bodur, Levent Akin, Berrrin Esen, Firdevs Aktas, Cihangir G. Gumustepe, Ismail Ceyhan, Ismet Battal, İbrahim Kosker, Ahmet Karakas, Cigdem Aydemir, Vedat Turhan, Hasan Irmak, I. Ercan Bal, Bekir Celebi and Husniye Simsek), to Nuket Tuzun Aral for her laboratory support, to Sefa Gungor, Kirami Olgen and Beycan Hocaoglu for mapping.
References

1. EpiSouth. EpiSouth Weekly Epi Bulletin - $\mathrm{N}^{\circ} 12718$ August 2010-24 August 2010. EpiSouth. 26 August 2010. Available from: http://www.episouth.org/cgi-bin/ searchbull?TEMP $=\_2 \& Q U A R T=20103$

2. Danis K, Papa A, Theocharopoulos G, Dougas G, Athanasiou M, Detsis $M$, et al. Outbreak of West Nile virus infection in Greece, 2010. Emerg Infect Dis. 2011;17(10):1868-72.

3. Sirbu A, Ceianu CS, Panculescu-Gatej RI, Vazquez A, Tenorio A, Rebreanu R, et al. Outbreak of West Nile virus infection in humans, Romania, July to October 2010. Euro Surveill. 2011;16(2):pii=19762. Available from: http://www. eurosurveillance.org/ViewArticle. aspx?Articleld $=19762$

4. Barzon L, Pacenti M, Cusinato R, Cattai M, Franchin E, Pagni S, et al. Human cases of West Nile Virus infection in north-eastern Italy, 15 June to 15 November 2010. Euro Surveill. 2011;16(33):pii=19949. Available from: http://www. eurosurveillance.org/ViewArticle. aspx?Articleld=19949

5. European Centre for Disease Prevention and Control (ECDC). ECDC Threat assessment. Review of epidemiological situation on West Nile virus infection in the European Union. September 3, 2010. Stockholm: ECDC. 3 September 2010. Available from: http://www.transfuznispolecnost.cz/doc/jine/ ReportWNV_201009.pdf

6. Health Protection Agency (HPA). West Nile virus activity, Europe 2011. London: HPA. [Accessed 24 May 2012]. Available from: http://www.hpa.org.uk/Topics/InfectiousDiseases/ InfectionsAZ/WestNileVirus/Generallnformation/ wnile04WestNileEurope2011/

7. European Centre for Disease Prevention and Control (ECDC). Epidemiological update: End of West Nile virus transmission season in Europe. Stockholm: ECDC, 25 Nov 2011. Available from: http://ecdc.europa.eu/en/press/news/Lists/News/ ECDC_DispForm.aspx?List=32e 43ee8-e230-4424-a78385742124029 a\&ID $=527 \&$ RootFolder $=/$ en/press/news/Lists/ News

8. Official Journal of the European Union 18.6.2008 L $159 / 46$. Commission Decision of 28 April 2008 amending Decision 2002/253/EC laying down case definitions for reporting communicable diseases to the Community network under Decision No 2119/98/EC of the European Parliament and of the Council (reference number C(2008) 1589) 2008/426/ EC. Available from: http://eur-lex.europa.eu/LexUriServ/ LexUriServ.do?uri=0J:L:2008:159:0046:0090:EN:PDF

9. Ozkul A, Yildirim Y, Pinar D, Akcali A, Yilmaz V, Colak D. Serological evidence of West Nile Virus (WNV) in mammalian species in Turkey. Epidemiol Infect. 2006;134 (4): 826-9.

10. Turkish Statistical Institute (TUIK). 2009 Address Based Population Registration System. [Accessed 15 Jan 2011]. Available from: http://www.tuik.gov.tr/PreHaberBultenleri. do? id $=8428 \&$ tb_id $=3$

11. Ministry of Food, Agriculture and Husbandry. [Official letter from Ministry of Food, Agriculture and Husbandry to Ministry of Health, Turkey, 11.01.2011]. Jan 2011. p. 1073-74. Turkish.

12. Serter D. Present status of arbovirus sero-epidemiology in the Aegean region of Turkey. In: Vesenjak-Hirjan J, Caliserh C, editors. Arboviruses in the Mediterranean countries. Stuttgart: Gustav Fischer Verlag; 1980. p. 155-61.

13. Ergunay K, Ozer N, Us D, Ozkul A, Simsek F, Kaynas S et al. Seroprevalence of West Nile virus and tick-borne encephalitis virus in Southeastern Turkey: first evidence for tick-borne encephalitis virus infections. Vector Borne Zoonotic Dis. 2007;7(2):157-161.

14. Ergünay K, Saygan MB, Aydogan S, Menemenlioğlu D, Turan HM, Ozkul A, et al. West Nile Virus seroprevalence in blood donors from Central Anatolia, Turkey. Vector Borne Zoonotic Dis. 2010;10(8):771-5.

15. Ergünay K, Aydoğan S, Menemenlioğlu D, Sener B, Lederer S, Steinhagen K, et al. [Investigation of West Nile virus in central nervous system infections of unknown etiology in Ankara, Turkey]. Mikrobiyol Bul. 2010;44(2):255-62. Turkish.

16. Mostashari F, Bunning ML, Kitsutani PT, Singer DA, Nash D, Cooper MJ, et al. Epidemic West Nile encephalitis, New York, 1999: results of a household-based seroepidemiological survey. Lancet. 2001;358(9278):261-4. 